УдК $633.522:[631+631.81+631.86]$

Пісковий М. Б., кандидат сільськогосподарських наук,

Магда М. А., стариий технолог-селекціонер ТОВ «НДІ сої», Пилипченко А. В., президент «ТОВ «НДІ сої», Ситник В. П., кандидат сільськогосподарських наук

ТОВ «Науково-дослідний інститут сої»

\title{
ВПЛИВ ТЕХНОЛОГІЙ ВИРОЩУВАННЯ КОНОПЕЛЬ НА ПОЖИВНИЙ СТАН ГРУНТУ
}

\section{Рецензент - доктор сільськогосподарських наук С. Л. Войтенко}

У статті викладені результати досліджень щчодо ефективності вирощування конопель в умовах класичної технології та органічного землеробства. Визначено, як технологія вирошування конопель впливає на зміну біологічного стану трунту, урожайність насіння та стебел, а також започатковано вивчення шляхів забезпечення культури конопель елементами живлення. Дослідженнями встановлено, щз вирошування конопель сорту Гляна в умовах органічного виробницттва не сприяє підвищенню урожайності насіння, порівняно із перехідною від класичної до біологічної технології (інтенсивною). Накопичення $і$ трансформачія свіжої органічної речовини рослинних решток конопель залежить від складових технологї органічного землеробства, які дають змогу мікрофлорі грунту не переносити стресових навантажень від впливу міндобрив і засобів захисту рослин.

Ключові слова: технологія вирощування, конопля, залежність між ознаками, поживність грунту, урожайність.

Постановка проблеми. Одним із головних завдань вирощування конопель в умовах органічного землеробства $\epsilon$ всебічний пошук шляхів забезпечення культури конопель елементами живлення. За умови, що внесення мінеральних добрив і зниження родючості грунту в органічному землеробстві не допустимо, шляхами забезпечення конопель макро- та мікроелементами можуть бути внесення органічних добрив, використання сидеральних культур, правильний підбір попередників, які б збагачували грунт елементами живлення, підтримували стабільний мікробний баланс та зберігали структуру грунту.

Перехід від класичної технології вирощування конопель посівних (Cannabis sativa L.) до технології органічного землеробства мають специфічні особливості та потребують детального вивчення i аналізу.

Аналіз останніх досліджень і публікацій, у яких започатковано розв'язання проблеми. Перші вітчизняні агротехнологи А. С. Хренников та М. Г. Городній, які вивчали умови жив- лення культури конопель, прийшли до висновку, що «У справі підвищення урожайності конопель одне 3 головних місць в комплексі прийомів культури повинно належати органічним та мінеральним добривам» $[14,7]$.

Дещо пізніше П. А. Горшковим, М. Г. Городнім і I. I. Реп'ях [4] зроблено ще більш категоричний висновок стосовно живлення конопель: «Коноплі дуже слабо ростуть на неудобреному фоні і сильно реагують на удобрення. Вирощувати коноплі на мінеральних грунтах без застосування добрив практично не можливо». Висновок про практичну неможливість вирощування конопель без використання добрив підтверджується Г. Р. Бідаком та I. I. Реп'ях у 1978 р. та П. А. Голобородьком і К. Я. Коротею $[1,8,9]$. У питанні живлення конопель дослідники $[3,2]$ констатують наступне:

- коноплі за своєю вимогливістю до наявності в грунті легкодоступних поживних речовин та реакцією на вдобрення займають одне 3 перших місць серед усіх культурних рослин;

- коноплі відносяться до групи сільськогосподарських культур, які з одиницею маси урожаю виносять 3 грунту велику кількість азоту, фосфору та калію (більшу ніж зернові, але не більшу багатьох інших рослин - льон, картопля, кукурудза (ствердження перших дослідників), більше ніж зернові, льон, цукровий буряк (ствердження дослідників, які вивчали коноплі пізніше));

- висока потреба конопель у наявності елементів живлення в грунті обумовлена двома біологічними особливостями культури: слабко розвиненою кореневою системою у порівнянні 3 надземною частиною і великим поглинанням елементів живлення у відносно короткий період росту і розвитку (період інтенсивного поглинання елементів живлення у південних конопель значно більший, ніж у середньоросійських, тому й урожайність перших у 2-3 рази вища останніх. Інтенсивне засвоєння азоту, фосфору та калію відбувається у різні періоди росту й розвитку конопель). Біологічна активність грунту 


\section{СІЛЬСЬКЕ ГОСПОДАРСТВО. РОСЛИННИЦТВО}

також підтримує динаміку інтенсивності грунтового розчину під час вирощування південних конопель.

Трансформація органічної речовини відіграє важливу роль для підтримки життя в біосфері. Рослини разом 3 мікроорганізмами потребують певних умов для свого росту і розвитку. Вони $є$ не лише споживачами, а й активними чинниками грунтової родючості. 3 рослинними рештками в грунт надходить у 1,5-3 рази більше сухої маси органічних речовин, ніж 3 органічними добривами. Процес трансформації і гуміфікації рослинних решток залежить від співвідношення вуглецю та азоту. Оптимальне співвідношення, в разі якого гуміфікація залишків відбувається найбільш повно, за даними Дудко 1 : 15-25 [6, 7], а за даними Кудеярова і Тарарико - 1 : 25-30 [11, 13]. Однорічні дослідження процесів трансформації органічної речовини рослинних решток конопель у динаміці дало змогу зробити припущення про специфічні закономірності. Так, вихідний вміст органічного вуглецю скоротився від початку вегетації до фази викидання суцвіть на 2,1 т/га, а до кінця вегетаційного періоду це зменшення становило лише 0,9 т/га $[5,12]$. Це пояснюється тим, що в процесі розвитку рослин конопель іде відмирання листя та коренів, які піддаються первинній деструкції мікроорганізмами. Активне розкладання свіжої органічної маси супроводжується накопиченням лабільних гумусних речовин або детриту - напіврозкладених рослинних решток, що втратили морфологічну структуру, i тому їх неможливо відокремити під час підготовки грунту до аналізу. Проведені дослідження целюлозолітичної активності грунту показали, що руйнування льняної тканини за класичної технології становило 23,8 \%, а в разі органічної - 35,2 \%. Вміст амоніфікуючих бактерій також був вищим (1,2 млн/г проти 0,9), азотфіксуючих (5,9 млн/г проти 4,7), мікроміцет $(93,2$ тис./Г проти 72,2) та стрептоміцети (0,7 тис./г проти 0,4 тис./г). Саме цей мікробний ценоз бере участь у первинній трансформації свіжої органічної речовини.

3 урахуванням вищевикладеного проведені дослідження мають за мету об'єктивно вивчити зміну технології вирощування конопель на зміну біологічного стану грунту, урожайність насіння та стебел.

Завдання досліджень - на основі польових та лабораторних досліджень протягом двох-трьох років відпрацювати елементи технології органічного землеробства та підготувати висновки i рекомендації виробництву.

Матеріали і методи досліджень. Аналіз урожайності коноплі сорту Гляна за різних технологій вирощування проведено в умовах холдингу «Арніка» Полтавської області в 2015-2016 роках. При цьому в ПП «Граніт-Агро» на площі 393 га використовували технологію органічного виробництва культури, а в ТОВ «Новомосковськ-Агро» на площі 404 га - класичну (перехідну від інтенсивної до органічної). В дослідженнях враховували показники наростання біомаси, біологічної врожайності насіння та стебел конопель, біологічної активності грунту (целюлозолітична активність, мікробний баланс грунту) та поживний стан грунту (вміст NPK та C), які визначали за загальноприйнятими в рослинництві методиками. Одержані результати досліджень опрацьовані методами математичної статистики.

Результати досліджень. За результатами наших досліджень встановлено, що у ПП «ГранітАгро», де вирощування конопель у 2016 році здійснювалось за технологією органічного землеробства, урожайність стебел і насіння в цілому по господарству і по кожному полю була нижчою у порівнянні з ТОВ «Новомосковськ-Агро», де технологія вирощування конопель була перехідною від класичної до біологічної. В середньому зменшення урожайності стебел становило $36,21 \%$, насіння дещо менше - 23,0 \% (табл. 1). Такий найбільш важливий елемент структури урожаю конопель, як середня густота стеблостою перед збиранням в обох господарствах був практично однаковим і становив 17,9 штук рослин на 1 м ${ }^{2}$ в «Граніт-Агро» і 17,2 - в «Новомосковськ-Агро». Хоча на окремих полях показники від мінімальних до максимальних становили від 13,3 до 20,2 в ПП «Граніт - Агро» і відповідно від 13,8 до 22,4 в ТОВ «Новомосковськ - Агро». Сто сімдесят тисяч рослин на гектарі конопель густота невелика для вирощування культури на двобічне використання - волокно та насіння. На цей показник дещо вплинула схожість насіння та погодні умови весни-літа 2016 року.

Висота рослин і середня маса 1-го стебла конопель у період збирання в «Граніт-Агро», як $\mathrm{i}$ урожайність, була нижчою в цілому по господарству і по кожному полю, ніж у «Новомосковськ-Агро». Зокрема, рослини, що вирощувались за технологією органічного землеробства мали висоту від 150 до 200,6 см, а вирощувані за класичною технологією - від 206,4 до 220,7 см.

Маса насіння 3 однієї рослини по господарству «Граніт-Агро» була нижчою на 38,66 \%, однак на полі X/2 більшою, ніж на полі II/3, IV/4 i VII/4 у «Новомосковськ-Агро». Змінюваність цього показника можна пояснити як природно кліматичними чинниками, так і впливом елементів технології на розвиток та формування рослин конопель. 


\section{СІЛЬСЬКЕ ГОСПОДАРСТВО. РОСЛИННИЦТВО}

\section{1. Біологічна урожайність конопель сорту Гляна за різних технологій вирощування культури}

\begin{tabular}{|c|c|c|c|c|c|c|c|c|c|c|c|c|c|}
\hline \multirow{3}{*}{ 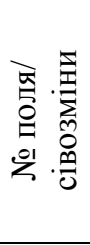 } & \multirow{3}{*}{$\begin{array}{l}\text { Пло- } \\
\text { ща, } \\
\text { га }\end{array}$} & \multicolumn{2}{|c|}{\begin{tabular}{|c|} 
Густота перед \\
збиранням
\end{tabular}} & \multicolumn{2}{|c|}{ Висота рослин } & \multicolumn{2}{|c|}{$\begin{array}{c}\text { Маса 1-го } \\
\text { стебла }\end{array}$} & \multicolumn{2}{|c|}{$\begin{array}{l}\text { Маса насіння } \\
3 \text { 1-ї рослини }\end{array}$} & \multicolumn{4}{|c|}{ Урожайність } \\
\hline & & \begin{tabular}{|l} 
серед- \\
\end{tabular} & & & & & & & & стеб & & насін & \\
\hline & & $\begin{array}{c}\text { ня, } \\
\text { шт./M² } \\
\mathrm{M} \pm \mathrm{m}\end{array}$ & $\begin{array}{c}\mathrm{Cv} * \\
\%\end{array}$ & $\begin{array}{c}\mathrm{cm} \\
\mathrm{M} \pm \mathrm{m}\end{array}$ & $\begin{array}{c}\mathrm{Cv} * \text {, } \\
\%\end{array}$ & $\begin{array}{c}\Gamma \\
\mathrm{M} \pm \mathrm{m}\end{array}$ & $\begin{array}{c}\mathrm{Cv} *, \\
\%\end{array}$ & $\begin{array}{c}\Gamma \\
\mathrm{M} \pm \mathrm{m}\end{array}$ & $\begin{array}{c}\mathrm{Cv} *, \\
\%\end{array}$ & $\begin{array}{c}\text { середня, } \\
ц / \text { га } \\
\mathrm{M} \pm \mathrm{m}\end{array}$ & $\begin{array}{c}\mathrm{Cv} *, \\
\%\end{array}$ & $\begin{array}{c}\text { середня, } \\
ц / г \mathrm{a} \\
\mathrm{M} \pm \mathrm{m}\end{array}$ & $\begin{array}{l}\mathrm{CV} \\
\%\end{array}$ \\
\hline
\end{tabular}

ПП «Граніт - Агро» (органічна технологія)

\begin{tabular}{|c|c|c|c|c|c|c|c|c|c|c|c|c|c|}
\hline VII/1 & 126,0 & $18,6 \pm 1,2$ & 15,0 & $150,0 \pm 8,8$ & 13,2 & $15,2 \pm 1,6$ & 10,9 & $3,59 \pm 0,52$ & 32,6 & $27,63 \pm 2,10$ & 17,0 & $6,49 \pm 0,78$ & 26,8 \\
\hline VIII/1 & 90,0 & $19,6 \pm 2,7$ & 31,3 & $200,6 \pm 10,3$ & 11,5 & $24,5 \pm 1,2$ & 11,4 & $2,81 \pm 0,33$ & 26,7 & $48,74 \pm 7,36$ & 33,8 & $5,26 \pm 0,59$ & 25,1 \\
\hline IX/1 & 97,0 & $20,2 \pm 3,2$ & 35,4 & $173,8 \pm 10,8$ & 14,0 & $18,2 \pm 3,5$ & 42,9 & $2,56 \pm 0,16$ & 14,1 & $32,64 \pm 3,05$ & 21,9 & $5,29 \pm 0,96$ & 40,3 \\
\hline X/2 & 80,0 & $13,3 \pm 1,2$ & 26,2 & $188,8 \pm 7,2$ & 7,7 & $31,9 \pm 5,5$ & 49,0 & $5,65 \pm 0,86$ & 37,2 & $39,97 \pm 4,91$ & 34,8 & $7,58 \pm 1,24$ & 40,1 \\
\hline Середнє: & $17,9 \pm 2,1$ & 27,0 & $178,3 \pm 9,3$ & 11,6 & $22,4 \pm 3,0$ & 28,6 & $3,65 \pm 0,47$ & 27,6 & $37,24 \pm 4,36$ & 26,9 & $6,16 \pm 0,89$ & 33,1 \\
\hline \multicolumn{10}{|c|}{ ТОВ «Новомосковськ - Агро» (класична технологія) } \\
\hline II/3 & 82,0 & $16,1 \pm 1,2$ & 18,0 & $209,1 \pm 9,9$ & 11,7 & $38,8 \pm 4,6$ & 28,8 & $5,01 \pm 1,33$ & 59,3 & $61,52 \pm 7,70$ & 30,7 & $7,41 \pm 1,19$ & 39,3 \\
\hline IV/4 & 158 & $19,0 \pm 0,9$ & 9,3 & $206,4 \pm 13,4$ & 14,6 & $32,5 \pm 2,9$ & 18,2 & $3,92 \pm 0,67$ & 38,3 & $61,62 \pm 6,06$ & 19,7 & $7,03 \pm 1,18$ & 37,8 \\
\hline V/4 & 61,9 & $13,8 \pm 1,7$ & 30,6 & $219,4 \pm 8,4$ & 8,5 & $46,0 \pm 7,2$ & 38,3 & $7,49 \pm 1,88$ & 56,5 & $57,84 \pm 2,70$ & 11,4 & $9,03 \pm 1,63$ & 40,4 \\
\hline VI/4 & 59,2 & $14,6 \pm 3,9$ & 59,5 & $220,7 \pm 10,8$ & 11,0 & $39,5 \pm 6,6$ & 36,9 & $8,20 \pm 2,14$ & 52,2 & $50,76 \pm 6,96$ & 30,7 & $9,05 \pm 1,04$ & 23,0 \\
\hline VII/4 & 73,0 & $22,4 \pm 6,5$ & 71,6 & $218,3 \pm 11,4$ & 10,5 & $35,5 \pm 8,3$ & 57,5 & $5,15 \pm 2,20$ & 95,5 & $60,17 \pm 7,66$ & 31,2 & $7,50 \pm 1,16$ & 34,5 \\
\hline Середнє: & $17,2 \pm 2,8$ & 37,8 & $214,8 \pm 10,8$ & 11,3 & $38,5 \pm 7,4$ & 35,9 & $5,95 \pm 1,64$ & 60,4 & $58,38 \pm 6,22$ & 24,7 & $8,00 \pm 1,24$ & 35,0 \\
\hline
\end{tabular}

Примітка: $\mathrm{Cv}^{*}-$ коефіціснт варіації

\section{2. Взаємозв'язок між урожайністю конопель та окремими елементами ії структури під час вирощування в умовах біологічного і інтенсивного землеробства}

\begin{tabular}{|l|c|c|c|c|}
\hline \multirow{2}{*}{\multicolumn{1}{|c|}{ Показники }} & \multicolumn{4}{|c|}{ Величина коефіціснта кореляції між: } \\
\cline { 2 - 5 } & $\begin{array}{c}\text { висотою } \\
\text { рослин }\end{array}$ & $\begin{array}{c}\text { масою 1-ї } \\
\text { рослини }\end{array}$ & $\begin{array}{c}\text { масою насіння } \\
\text { з 1-ї рослини }\end{array}$ & $\begin{array}{c}\text { густотою пе- } \\
\text { ред збиранням }\end{array}$ \\
\hline $\begin{array}{l}\text { Середня урожайність насіння } \\
\text { в господарствах }\end{array}$ & - & - & $+0,97 \pm 0,02$ & $-0,65 \pm 0,18$ \\
\hline $\begin{array}{l}\text { Середня урожайність стебел } \\
\text { в господарствах }\end{array}$ & $+0,89 \pm 0,09$ & $+0,81 \pm 0,11$ & - & $+0,62 \pm 0,20$ \\
\hline $\begin{array}{l}\text { Урожайність насіння в } \\
\text { ПП «Граніт-Агро» }\end{array}$ & - & - & $0,97 \pm 0,04$ & $-0,94 \pm 0,06$ \\
\hline $\begin{array}{l}\text { Урожайність стебел в } \\
\text { ПП «Граніт-Агро» }\end{array}$ & $+0,96 \pm 0,03$ & $+0,68 \pm 0,26$ & - & $+0,71 \pm 0,24$ \\
\hline $\begin{array}{l}\text { Урожайність насіння в } \\
\text { «Новомосковськ-Агро» }\end{array}$ & - & - & $+0,99 \pm 0,02$ & $-0,73 \pm 0,21$ \\
\hline $\begin{array}{l}\text { Урожайність стебел в } \\
\text { «Новомосковськ-Агро» }\end{array}$ & $+0,73 \pm 0,18$ & $+0,96 \pm 0,02$ & - & $+0,52 \pm 0,36$ \\
\hline Висота рослин & - & $0,89 \pm 0,07$ & - & - \\
\hline Маса 1-ї рослини & - & - & - & $-0,52 \pm 0,26$ \\
\hline Маса насіння з 1-ї рослини & - & - & - & $-0,70 \pm 0,16$ \\
\hline
\end{tabular}

Між урожайністю стебел і насінням конопель та окремими елементами їі структури встановлено певний взаємозв'язок (табл. 2). Особливо висока пряма залежність виявлена між урожайністю насіння і масою насіння з 1-ї рослини. Коефіцієнт кореляції близький до одиниці $(+0,97 \ldots$ $+0,99)$. Дещо менший, але позитивний кореляційний зв'язок існує у конопель між урожайністю стебел і висотою рослин $(\mathrm{r}=+0,73 \ldots+0,96)$ та урожайністю стебел і масою 1-ї рослини $(\mathrm{r}=+0,68 \ldots+0,96)$. Відмічено різну залежність між густотою стеблостою перед збиранням та урожайністю насіння і стебел конопель. Позитивний середній рівень кореляційного зв'язку виявлений між урожайністю стебел і густотою $(\mathrm{r}=+0,52 \ldots+0,71)$ і від'ємний, від середнього до високого, між урожайністю насіння і густотою стеблостою $(\mathrm{r}=-0,65 \ldots-0,94)$. 


\section{СІЛЬСЬКЕ ГОСПОДАРСТВО. РОСЛИННИЦТВО}

Маса однієї рослини й маса насіння 3 однієї рослини знаходяться в зворотній залежності від густоти стеблостою перед збиранням, що підтверджують коефіцієнти кореляції між ознаками ( $\mathrm{r}=-0,52$ і -0,70). У прямій залежності знаходиться висота і маса однієї рослини у конопель $(\mathrm{r}=+0,89)$.

Умови вирощування конопель, зокрема органічне землеробство в «Граніт-Агро» чи перехідне землеробство в «Новомосковськ-Агро», яке використовувалось у процесі вирощування культури, не впливають на рівень зв'язку між показниками урожайності й елементами структури цієї урожайності: висотою рослин, масою 1-ї рослини, масою насіння 3 1-ї рослини та густотою. Величина коефіцієнта кореляції в кожному із випадків знаходилася на одному рівні.

Одержані результати досліджень не дають змоги стверджувати, що більш низьку урожайність насіння та стебел, нижчу висоту рослин i середню масу 1-го стебла конопель у господарстві «Граніт-Агро» у порівнянні 3 «Новомосковськ-Агро» зумовило лише застосування органічного землеробства в коноплярстві. Під час порівняння даних двох технологій порушується основний принцип дослідницької справи принцип єдиної відмінності. В обох господарствах висівався один і той же сорт конопель Гляна, практично однаковою була густота стебел конопель перед збиранням, практично однакова технологія вирощування, біологічне дозрівання конопель було також майже одночасним, однак родючість й кислотність грунту, передпопередники та попередники конопель у «Граніт-Агро» $\mathrm{i}$
«Новомосковськ-Агро» були різними (табл. 3).

Фосфор і калій є одними із основних біогенних елементів живлення рослин. Оптимізація умов живлення цими елементами конопель відноситься до першочергових. Виключення фосфору і калію із поживного середовища на ранніх фазах розвитку значно уповільнює ріст і знижує урожай конопель.

Маючи у розпорядженні показники вмісту рухомих форм фосфору та калію в грунті (табл. 3) відмічаємо, що коноплі в кожному 3 господарств по-різному були забезпечені цими мінеральними елементами протягом вегетації. У ПП «ГранітАгро» кращим за вмістом у грунті рухомих форм фосфору та калію було поле № X-2, а у ТОВ «Новомосковськ-Агро» за вмістом фосфору - поля № V-4 і VII-4, за вмістом калію - поле № II-3.

Не випадково, урожайність соломи й волокна конопель у «Граніт-Агро» була кращою на полі $\mathrm{X}-2$, яке найкраще забезпечено фосфором і калієм. У «Новомосковськ-Агро» найбільша урожайність соломи була на полях II-3, IV-4 і VII-4, урожайність насіння - на полях V-4 і VI-4.

Для визначення рівня зв'язку між показниками вмісту в грунті рухомих форм фосфору й калію та урожайністю конопель як в цілому по господарствах, так і в кожному з господарств провели кореляційний аналіз. Результати досліджень засвідчили, що урожайність насіння і стебел конопель більшою мірою залежить від вмісту в грунті рухомих форм фосфору, ніж калію (табл. 4). Вирощування конопель в умовах органічного землеробства не впливає на таку залежність.

\section{3. Характеристика шару трунту 0-20 см та попередників конопель по полях сівозмін (2016 р.)}

\begin{tabular}{|c|c|c|c|c|c|}
\hline $\begin{array}{c}\text { № } \\
\text { поля- } \\
\text { сівозміни }\end{array}$ & $\begin{array}{c}\text { Площа } \\
\text { поля, га }\end{array}$ & $\mathrm{pH}$ & $\begin{array}{c}\mathrm{P}_{2} \mathrm{O}_{5} \\
\text { мг/кг } \\
\text { грунту }\end{array}$ & $\begin{array}{c}\mathrm{K}_{2} \mathrm{O} \\
\text { мг/кг } \\
\text { грунту }\end{array}$ & $\begin{array}{c}\text { Передпопередник, } \\
\text { попередник конопель }\end{array}$ \\
\hline & \multicolumn{5}{|c|}{ ПП «Граніт-Агро» } \\
\hline VII-1 & 126,0 & 6,2 & 10,9 & 8,6 & Кукурудза $\rightarrow$ Кукурудза \\
\hline VIII-1 & 90,0 & 7,0 & 14,5 & 7,9 & Соя $\rightarrow$ Озима пшениця \\
\hline IX-1 & 97,0 & 6,8 & 11,3 & 9,3 & Соя $\rightarrow$ Озима пшениця \\
\hline X-2 & 80,0 & 7,0 & 15,4 & 17,2 & Соя $\rightarrow$ Соя \\
\hline \multicolumn{5}{|c|}{ ТОВ «Новомосковськ-Агро» } & Соя $\rightarrow$ Соя $\rightarrow$ Соя \\
\hline II-3 & 82,0 & 7,3 & 15,7 & 19,1 & $\begin{array}{c}\text { Соя } \rightarrow \text { Оз. ячм., } \\
\text { Кукур. } \rightarrow \text { Соняшн. }\end{array}$ \\
\hline IV-4 & 158,0 & 6,7 & 14,3 & 10,3 & Соя $\rightarrow$ Кукурудза $\rightarrow$ Соняшник \\
\hline V-4 & 61,9 & 6,6 & 22,5 & 13,8 & Соя $\rightarrow$ Кукурудза $\rightarrow$ Соняшник \\
\hline VI-4 & 59,2 & 6,9 & Чорнозем глибоко \\
солонц. & 21,9 & 14,9 & Соя $\rightarrow$ Кукурудза $\rightarrow$ Соняшник \\
\hline VII-4 & 73,0 & 6,7 & \multicolumn{5}{|c|}{}
\end{tabular}


СІЛЬСЬКЕ ГОСПОДАРСТВО. РОСЛИННИЦТВО

\section{4. Взаємозв'язок між урожайністю конопель та вмістом в грунті рухомих форм} $\mathrm{P}_{2} \mathrm{O}_{5}$ i $\mathrm{K}_{2} \mathrm{O}$ в умовах біологічного і інтенсивного землеробства

\begin{tabular}{|c|c|c|c|c|c|c|}
\hline \multirow{3}{*}{$\begin{array}{c}\text { Показ- } \\
\text { ники }\end{array}$} & \multicolumn{6}{|c|}{ Величина коефіцієнта кореляції між: } \\
\cline { 2 - 7 } & $\begin{array}{c}\text { середня по го- } \\
\text { сподарствах }\end{array}$ & $\begin{array}{c}\text { «Граніт- } \\
\text { Агро» }\end{array}$ & $\begin{array}{c}\text { «Новомос- } \\
\text { ковськ-Агро» }\end{array}$ & $\begin{array}{c}\text { середня по го- } \\
\text { сподарствах }\end{array}$ & $\begin{array}{c}\text { «Граніт- } \\
\text { Агро» }\end{array}$ & $\begin{array}{c}\text { «Новомос- } \\
\text { ковськ-Агро» }\end{array}$ \\
\hline $\mathrm{P}_{2} \mathrm{O}_{5}$ & 0,76 & 0,85 & 0,85 & 0,70 & 0,83 & 0,87 \\
\hline $\mathrm{K}_{2} \mathrm{O}$ & 0,67 & 0,38 & 0,05 & 0,46 & 0,10 & 0,09 \\
\hline
\end{tabular}

5. Фактична та біологічна урожайність і валовий збір насіння конопель по господарствам агрохолдингу, 2016 р.

\begin{tabular}{|c|c|c|c|c|c|}
\hline \multirow{2}{*}{$\begin{array}{c}\text { Назва } \\
\text { господарства }\end{array}$} & \multirow{2}{*}{$\begin{array}{c}\text { Площа посіву } \\
\text { конопель, га }\end{array}$} & \multicolumn{2}{|c|}{ Урожайність насіння, т/га } & \multicolumn{2}{|c|}{ Валовий збір насіння, т } \\
\cline { 5 - 6 } & Факична & біологічна & фактичний & $\begin{array}{c}\text { біологічний } \\
\text { (розрахунок) }\end{array}$ \\
\hline $\begin{array}{c}\text { ПГраніт- } \\
\text { Агро» }\end{array}$ & 393,0 & 0,471 & 0,616 & 185,057 & 242,088 \\
\hline $\begin{array}{c}\text { ТОВ «Новомос- } \\
\text { ковськ-Агро» }\end{array}$ & 434,1 & 0,666 & 0,800 & 289,187 & 347,280 \\
\hline
\end{tabular}

Об'єктивно оцінити роль попередника в формуванні урожайності конопель у «Граніт-Агро» і «Новомосковськ-Агро» в 2016 році неможливо. У господарстві «Граніт-Агро», де коноплі вирощувались за умов органічного землеробства, кращим попередником конопель була соя на полі X-2, гіршим - кукурудза на полі VII-1. Урожайність стебел і насіння в цьому господарстві дійсно була вищою саме на полі X-2, відповідно 39,97 i 7,58 ц/га. Однак поле X-2 було кращим i за вмістом у грунті елементів живлення - фосфору та калію. Урожайність стебел на полі VII-1 була найменшою по господарству - 27,63 ц/га, а насіння $(6,49$ ц/га) більшою, ніж на полях VIII-1 i IX-1, де попередником була озима пшениця.

У «Новомосковськ-Агро» кращим попередником конопель на полі II-3 була соя, а гіршим соняшник на решті полів. Водночас урожайність насіння і соломи конопель була не найкращою по господарству на полі II-3.

Простежити будь-яку залежність між кислотністю грунту та урожайністю конопель не можливо. Показник кислотності полів в обох господарствах, за даними комплексного обстеження грунтів, що проведені в 2014 році, знаходився в межах 6,2-7,3 рН одиниць, засвідчуючи несуттеву різницю в якості. Кислотність грунтів більшості полів була нейтральною або близькою до нейтральної. Для культури конопель така кислотність оптимальна для росту і розвитку. Нашими дослідженнями встановлено, що урожайність насіння і стебел конопель змінювалась незалежно від кислотності грунту.
Фактична і біологічна урожайність та валовий збір насіння конопель у розрізі господарств із різною технологією вирощування культури у 2016 році наведена в таблиці 5 , дає змогу зробити висновок про перевагу фактичної урожайності насіння конопель на 0,195 т/га та біологічної на 0,184 т/га в ТОВ «Новомосковськ-Агро», порівняно із ПП «Граніт-Агро». Тобто, органічне виробництво конопель не сприяє підвищенню урожайності конопель, порівняно $з$ інтенсивною технологією.

\section{Висновки:}

1. Вирощування конопель сорту Гляна в умовах органічного виробництва не сприяє підвищенню урожайності насіння, порівняно із перехідною від класичної до біологічної технології (інтенсивною), що може пояснюватися відсутністю внесення мінеральних добрив та засобів захисту рослин конопель.

2. Доведено існування кореляційного зв'язку між показниками урожайності культури й окремими елементами структури урожаю та показниками родючості грунту, які дають змогу проводити добір за однією із них для покращання іншої чи зменшення кількості ознак селекції.

3. Експериментально встановлено, що на накопичення і трансформацію свіжої органічної речовини рослинних решток конопель істотно впливають елементи технології органічного землеробства, які дають змогу мікрофлорі грунту не переносити стресових навантажень від впливу міндобрив і засобів захисту рослин. 


\section{БІБЛІОГРАФІЯ}

1. Бедак Г. Р. Система удобрения / Г. Р. Бедак, И. И. Репях // Конопля. - М. : Колос, 1978. C. 115-145.

2. Вернадський В. И. Биосфера / В. И. Вернадський // Избранные труды. - М. : Мысль, 1967. $376 \mathrm{c}$.

3. Голобородько П. А., Коротя К. Я. Система удобрення / П. А. Голобородько, К. Я. Коротя // Коноплі. - Суми : Еллада, 2011. - С. 183-194.

4. Горшков П. А. Применение удобрений под коноплю / П. А. Горшков, Н. Г. Городний, И. И. Репях // Конопля. - М. : Сельхозиздат, 1963. - C. 159-191.

5. Гудзь В. П. Вплив негуміфікованої органічної речовини на грунтово-мікробіологічні процеси при вирощуванні кукурудзи на зерно / В. П. Гудзь, О. Ю. Карпенко, Т. С. Шроль // Вісник аграрної науки. - 1998. - №4. - С. 14-15.

6. Кудеяров В. Н. Оценка размеров несимбиотической азотфиксации в почве методом баланса / В. Н. Кудеяров, Т. В. Кузнецова // Почвоведение. - 1990. - №11. - С. 79-89.

7. Міщенко С. В. Кореляційні зв'язки між основними канабіноїдними сполуками рослин сучасних безнаркотичних сортів конопель / С. В. Міщенко // Вісник Полтавської державної аграрної академії. - 2012. - №2. - С. 65-69.

8. Мигаль М. Д., Кабанещь В. М. Коноплі /
М. Д. Мигаль, В. М. Кабанець. - Суми : Видавничий будинок «Еллада», 2011. - 384 с.

9. Перспективи переорієнтації селекції конопель для створення сортів медичного напрямку використання / [Лайко І. М., Міщенко С. В., Орлов М. М., Маринченко І. О., Шкурдода С. В., Пасічник В. В.] // Збірник наукових праць Інституту біоенергетичних культур і цукрових буряків НААН України. - 2015. - Вип. 23. - С. 107-112.

10. Рева П. П., Кулинич Л. Я. Екологія для всіх / П. П. Рева, Л. Я. Кулинич. - К. : Вища школа, 1985. - C. 55.

11. Сучасні технології відтворення родючості грунтів та підвищення продуктивності агроекосистем / [за редакцією Ю. О. Тараріко]. - К. : Аграрна наука, 2004. - С. 52.

12. Тараріко Ю. О. Біоенергетична оцінка ефективності застосування добрив в зерновопросапних сівозмінах / Ю. О. Тараріко, О. А. Андрійченко // Агроекологічний журнал. - 2000. №2. - С. 16.

13. Фокин Д. В. Участие микроорганизмов в трансформации гумуса почв / Д. В. Фокин, Л. М. Дмитраков, О. А. Соколов // Агрохимия. 1999. - №9. - С. 79-91.

14. Хренников А.С. Удобрение конопли / А. С. Хренников, Н. Г. Городний // Конопля. М. : Сельхозгиз, 1938. - С. 250-276. 